Annals of Warsaw University of Life Sciences - SGGW

Land Reclamation No 45 (2), 2013: 217-226

(Ann. Warsaw Univ. of Life Sci. - SGGW, Land Reclam. 45 (2), 2013)

\title{
Laboratory assessment of permeability of sand and biopolymer mixtures
}

\author{
MATEUSZ WISZNIEWSKI ${ }^{1}$, ZDZISLAW SKUTNIK ${ }^{2}$, ALI FIRAT CABALAR ${ }^{1}$ \\ ${ }^{1}$ Department of Civil Engineering, University of Gaziantep \\ ${ }^{2}$ Department of Civil Engineering, Warsaw University of Life Sciences - SGGW
}

\begin{abstract}
Laboratory assessment of permeability of sand and biopolymer mixtures. This research presents a method of creating seepage barriers in a sandy soil using biopolymer additives (biosubstance), which consist of polysaccharides and water. Polysaccharides strongly interact with water to produce a viscous suspension. The paper aims to investigate the influence of a biosubstance employed in a highly permeable sandy soil. Amount of the biopolymer used in a sample were $0.5,1.0$ and $1.5 \%$, by dry weight. The test results indicate that the hydraulic conductivity significantly decrease with the amount of biosubstance added but only slightly increase when curing time gets longer. It is thought that such application, which is a relatively new soil improvement technique, could be used as a seepage barrier installation required to protect some geotechnical works including foundation, underground structures and waste disposals.
\end{abstract}

Key words: biopolymers, permeability, seepage barrier

\section{INTRODUCTION}

Over the past years, many types of chemicals have been used for a geotechnical application. Chemical grouts are mostly toxic and hazardous for the environment. This constantly pushes researchers to find alternative eco-friendly techniques of ground improvement. It comes to light that several natural biopolymers have important characteristics, such as excellent viscosifying in high-salinity waters, pseudo plasticity, stability at large ranges of temperature and $\mathrm{pH}$, jellifying agents and resistance to shear degradation.

The use of biopolymers for soil improvement is already described in readily available literature. Several studies (Feldman 1989, Li et al. 1993, Martin et al. 1996, Stewart and Fogler 2001) have investigated the application of biopolymers as plugging agents in construction of various impervious barriers. Some researchers (Karimi 1997, Momeni et al. 1999, Khachatoorian et al. 2003) demonstrated the capacity of certain biopolymers, including xanthan gum and sodium alginate to decrease the permeability and increase the shear strength, thus reduce the leaching of contaminants.

While most of the investigations focus on fine, cohesive soil, the present research analyzes the potential use of biopolymer, namely xanthan gum, to reduce hydraulic conductivity of medium grain size sand. This part of research which should be regarded as a preliminary to investigate the influence of the biopolymer content on the reduction of the soil permeability.

\section{MATERIAL AND METHODS}

The materials used in the tests described in this paper were quartz medium sand and xanthan gum. The commercially 
available sand was obtained from regional sources near Warsaw. The specific gravity of the grains was found to be 2.68. A gradation of the sand falling between 1.00 and $0.071 \mathrm{~mm}$ was artificially selected. The grain size distribution curve of medium sand taken for the investigations is presented in Figure 1, while index properties of this soil in Table 1. from the bacteria Xanthomonas campestris. Xanthan gum is as a hydrophilic colloid to thicken and stabilize water-based suspensions. It is widely used in the drilling industry to thicken drilling fluids, and is very stable under various values of temperature and $\mathrm{pH}$ (Bouazza et al. 2009).

Samples were prepared by mixing sandy soil with xanthan gum by dry

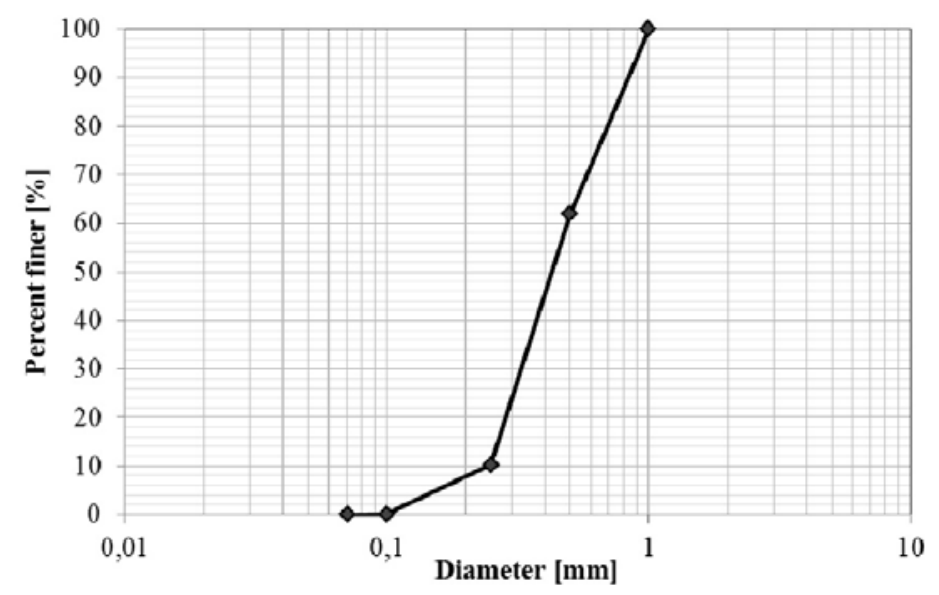

FIGURE 1. Particle size distribution curve

TABLE 1. Index properties of the sand

\begin{tabular}{|l|c|}
\hline Property & Value \\
\hline Minimum void ratio, $e_{\min }$ & 0.45 \\
\hline Maximum void ratio, $e_{\max }$ & 0.70 \\
\hline Relative density, $R_{D}$ & $45 \%$ \\
\hline Uniformity coefficient, $C_{u}$ & 1.96 \\
\hline Curvature coefficient, $C_{c}$ & 0.84 \\
\hline
\end{tabular}

Soil contains rectangular quartz grains with coefficient of uniformity $-C_{u}=1.96$ and coefficient of curvature $-C_{c}=0.84$.

The commercially available biopolymer material was obtained from a local food store in a powder form. Worldwide production of xanthan gum comes out weight. Four different mixtures were prepared, containing respectively 0.0 , $0.5,1.0$ and $1.5 \%$ of biopolymer. The required amounts of sandy soils and xanthan gum were blended together under dry conditions. Firstly sand was washed and dried in an oven at approximately $105^{\circ} \mathrm{C}$. For all the tests samples were prepared at relative density $45 \%$.

For the initial sand-xanthan gum-water specimen, the desired amount of the sand and xanthan gum were weighed, mixed, water was added, reaching $10 \%$ of each dry sample weight and then all was spooned, without vibration, into the mould (with a diameter of $69 \mathrm{~mm}$, and height of $70 \mathrm{~mm}$ ) with thin layers of 
sand. When the mould was completely filled, using plastic bags and foil it was tightly sealed to prevent moisture loose. Then samples were left for conditioning, respectively for $1,3,7,14$, and 28 days of time. Permeability apparatus with the specimen can be seen in Figures 2 and 3.

The permeability tests were conducted on clean sands and sand with xanthan gum at three different contents. A series of constant head permeability tests were performed according to ASTM D2434. Tests were conducted in a triaxial cell, where hydraulic gradient and confining pressure were controlled (Lipiński et al. 2007). All samples were made saturated from the bottom to top. Pressure at the top of each sample was set to be $0 \mathrm{kPa}$, while at the bottom applied pressure took values of $5,10,20,30,50$ and

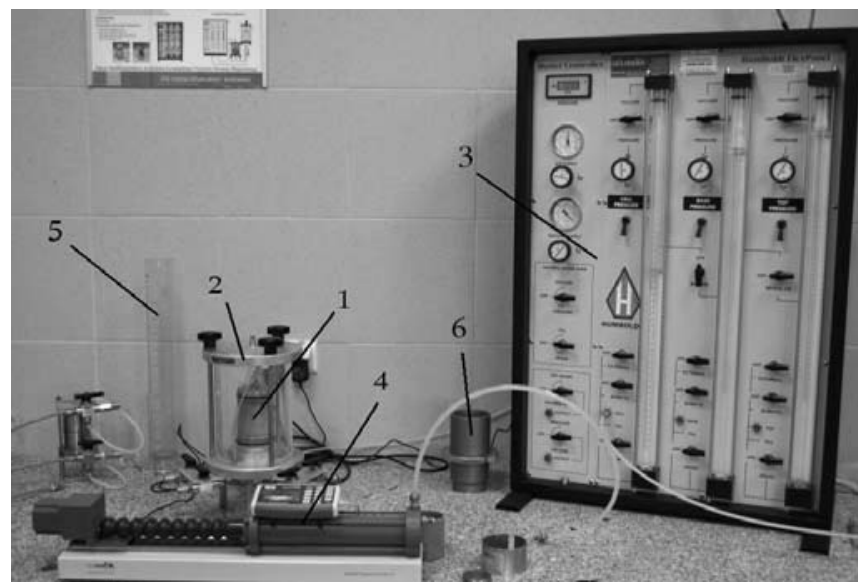

FIGURE 2. Permeability apparatus: 1 - specimen; 2 - triaxial cell, 3 - cell pressure controller; 4 - pore water controller; 5 - out-flow cylinder; 6 - sample mould

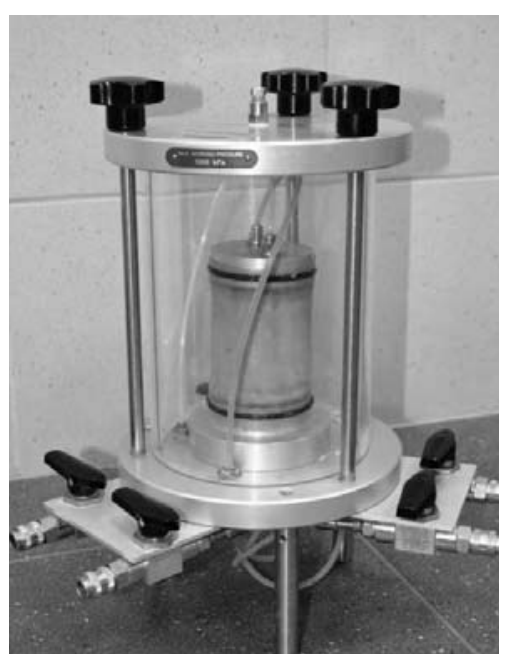

FIGURE 3. Permeability cell
$100 \mathrm{kPa}$ (Head 1995). Confining pressure in the cell was set to be $50 \mathrm{kPa}$ (for bottom pressure of 5, 10, 20 and $30 \mathrm{kPa})$, $100 \mathrm{kPa}$ (for $50 \mathrm{kPa}$ ) and $200 \mathrm{kPa}$ (for $100 \mathrm{kPa}$ ). The hydraulic conductivity of each sample was reported by the average of the last three measurements. All tests were conducted under room temperature $\left(22^{\circ} \mathrm{C}\right)$.

\section{RESULTS AND DISCUSSIONS}

The testing results on hydraulic conductivity of biopolymer treated sand are shown in Table 2. Permeability (hydraulic conductivity) decreases when more 
TABLE 2. Hydraulic conductivity of biopolymer treated sand for various curing time

\begin{tabular}{|c|c|c|c|c|c|c|c|}
\hline \multirow{2}{*}{$\begin{array}{c}\text { Biopoly- } \\
\text { mer ratio } \\
{[\%]}\end{array}$} & \multirow{2}{*}{$\begin{array}{c}\text { Curing } \\
\text { time } \\
{[\text { days }]}\end{array}$} & \multicolumn{7}{|c|}{ Permeability [m/s] } \\
\cline { 3 - 8 } & & 5 & 10 & 20 & 30 & 50 & 100 \\
\hline \multirow{4}{*}{0.5} & 1 & $8.65 \cdot 10^{-10}$ & $9.02 \cdot 10^{-10}$ & $1.13 \cdot 10^{-8}$ & $8.71 \cdot 10^{-8}$ & $5.25 \cdot 10^{-7}$ & $1.55 \cdot 10^{-6}$ \\
\cline { 2 - 8 } & 3 & $6.26 \cdot 10^{-10}$ & $2.42 \cdot 10^{-9}$ & $5.30 \cdot 10^{-8}$ & $3.76 \cdot 10^{-7}$ & $1.33 \cdot 10^{-6}$ & $1.83 \cdot 10^{-6}$ \\
\cline { 2 - 8 } & 7 & $4.25 \cdot 10^{-9}$ & $4.42 \cdot 10^{-9}$ & $9.89 \cdot 10^{-8}$ & $9.75 \cdot 10^{-7}$ & $1.45 \cdot 10^{-6}$ & $2.14 \cdot 10^{-6}$ \\
\cline { 2 - 8 } & 14 & $3.12 \cdot 10^{-9}$ & $4.92 \cdot 10^{-8}$ & $2.80 \cdot 10^{-7}$ & $7.49 \cdot 10^{-7}$ & $1.68 \cdot 10^{-6}$ & $2.35 \cdot 10^{-6}$ \\
\cline { 2 - 8 } & 28 & $3.14 \cdot 10^{-8}$ & $2.03 \cdot 10^{-7}$ & $9.02 \cdot 10^{-7}$ & $1.53 \cdot 10^{-6}$ & $2.67 \cdot 10^{-6}$ & $2.59 \cdot 10^{-6}$ \\
\hline \multirow{4}{*}{1.0} & 1 & $1.18 \cdot 10^{-10}$ & $1.24 \cdot 10^{-10}$ & $4.67 \cdot 10^{-10}$ & $7.23 \cdot 10^{-10}$ & $7.12 \cdot 10^{-9}$ & $1.98 \cdot 10^{-7}$ \\
\cline { 2 - 8 } & 3 & $3.68 \cdot 10^{-10}$ & $3.94 \cdot 10^{-10}$ & $7.07 \cdot 10^{-10}$ & $2.75 \cdot 10^{-9}$ & $1.79 \cdot 10^{-8}$ & $9.09 \cdot 10^{-7}$ \\
\cline { 2 - 8 } & 7 & $4.98 \cdot 10^{-10}$ & $5.54 \cdot 10^{-10}$ & $6.74 \cdot 10^{-10}$ & $3.81 \cdot 10^{-9}$ & $3.75 \cdot 10^{-8}$ & $1.29 \cdot 10^{-6}$ \\
\cline { 2 - 8 } & 14 & $2.12 \cdot 10^{-9}$ & $2.64 \cdot 10^{-9}$ & $1.47 \cdot 10^{-8}$ & $7.17 \cdot 10^{-8}$ & $4.09 \cdot 10^{-7}$ & $1.42 \cdot 10^{-6}$ \\
\cline { 2 - 8 } & 28 & $2.69 \cdot 10^{-9}$ & $2.50 \cdot 10^{-9}$ & $5.56 \cdot 10^{-9}$ & $2.00 \cdot 10^{-7}$ & $3.34 \cdot 10^{-7}$ & $1.03 \cdot 10^{-6}$ \\
\hline \multirow{4}{*}{1.5} & 1 & $2.84 \cdot 10^{-11}$ & $7.33 \cdot 10^{-11}$ & $1.28 \cdot 10^{-10}$ & $2.20 \cdot 10^{-10}$ & $5.08 \cdot 10^{-11}$ & $9.25 \cdot 10^{-8}$ \\
\cline { 2 - 8 } & 3 & $3.40 \cdot 10^{-11}$ & $3.38 \cdot 10^{-11}$ & $1.54 \cdot 10^{-10}$ & $7.53 \cdot 10^{-11}$ & $2.59 \cdot 10^{-11}$ & $7.90 \cdot 10^{-8}$ \\
\cline { 2 - 8 } & 7 & $4.39 \cdot 10^{-11}$ & $3.90 \cdot 10^{-11}$ & $7.73 \cdot 10^{-11}$ & $4.91 \cdot 10^{-11}$ & $3.20 \cdot 10^{-11}$ & $1.41 \cdot 10^{-7}$ \\
\cline { 2 - 8 } & 14 & $2.18 \cdot 10^{-11}$ & $2.51 \cdot 10^{-11}$ & $1.20 \cdot 10^{-10}$ & $7.98 \cdot 10^{-10}$ & $2.70 \cdot 10^{-10}$ & $6.39 \cdot 10^{-7}$ \\
\cline { 2 - 8 } & 28 & $6.84 \cdot 10^{-11}$ & $5.69 \cdot 10^{-11}$ & $2.80 \cdot 10^{-10}$ & $7.27 \cdot 10^{-10}$ & $8.66 \cdot 10^{-10}$ & $1.99 \cdot 10^{-7}$ \\
\hline
\end{tabular}

xanthan gum is added to the sample. For example, addition of just $0.5 \%$ xanthan gum to the sand decreases the permeability to almost $0.001 \%$ of the initial value. Addition of $1.5 \%$ xanthan gum changes the permeability from $8.46 \cdot 10^{-5} \mathrm{~m} / \mathrm{s}$ to about $2.84 \cdot 10^{-11} \mathrm{~m} / \mathrm{s}$, which is less than $1,000,000$ times.

Figure 4 presents three graphs with different xanthan gum (biopolymer) content, where the changes of permeability, according to the hydraulic gradient applied for various curing time are shown. It is seen that hydraulic conductivity increases as the applied pressure increases, and as the curing time gets longer. Permeability of the specimens remains low, under greater hydraulic gradient for higher xanthan gum ratio. As presented in the graph for $1.5 \%$ biopolymer content, wa- ter flow through the sand is stable, for all the samples (different curing times) for a hydraulic gradient up to 70 . In that case improved sand might be considered as impermeable, reaching values between $2.18 \cdot 10^{-11}$ and $8.66 \cdot 10^{-10} \mathrm{~m} / \mathrm{s}$.

Effect of time on hydraulic conductivity of the soil biopolymer mix under various pressures is shown in Figure 5. When the long-term behavior of seepage barriers is a main objective, observing short-term behavior is a good evidence of the possible technology development. A longer ageing time generally achieved a lower conductivity, but work with coarse and medium sand shows different relationship (Fig. 5). It can realized that the permeability (hydraulic conductivity) of a biopolymer treated sand increases with time, for the $0.5 \%$ mixture 

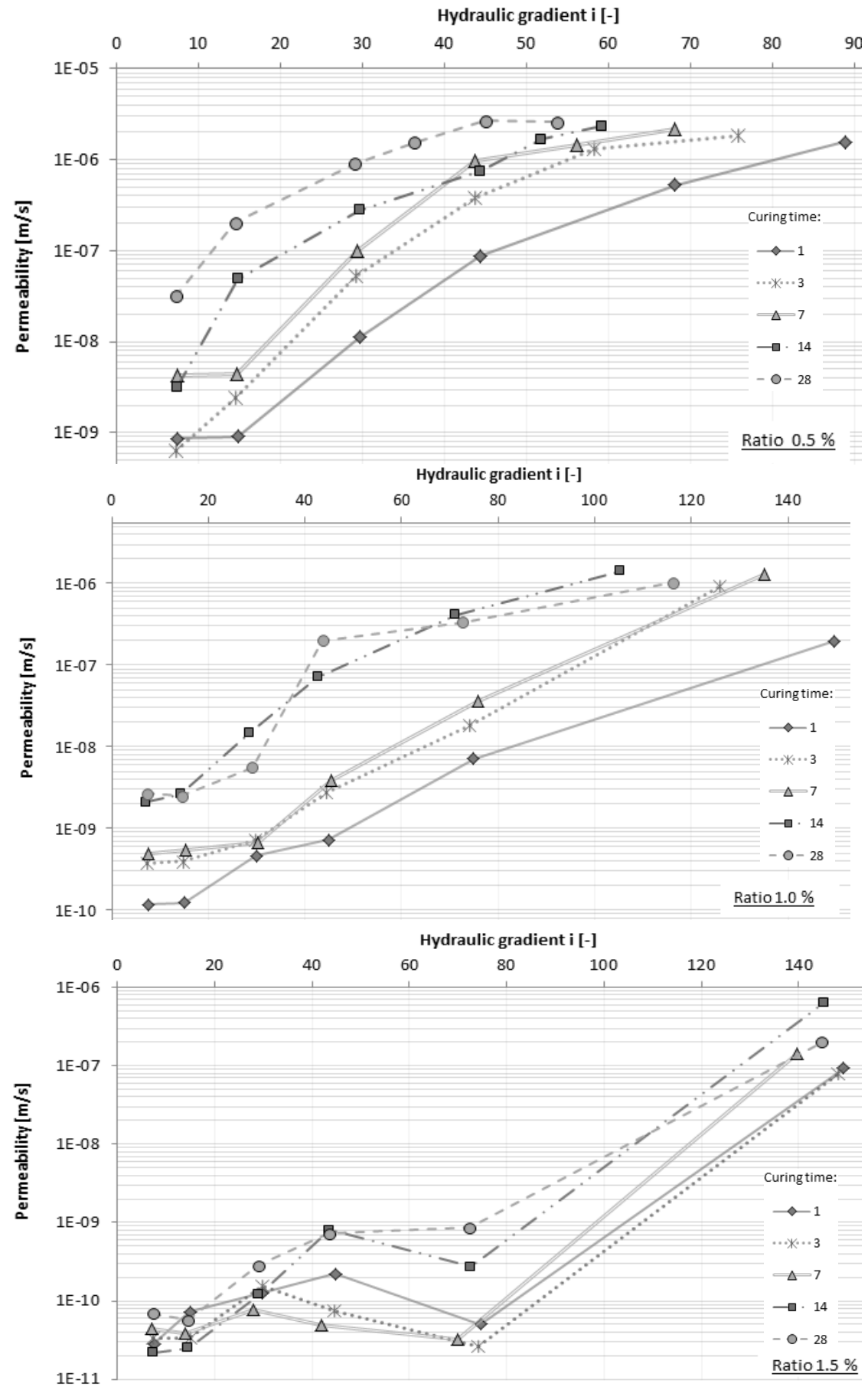

FIGURE 4. Hydraulic conductivity of a biopolymer treated sand 

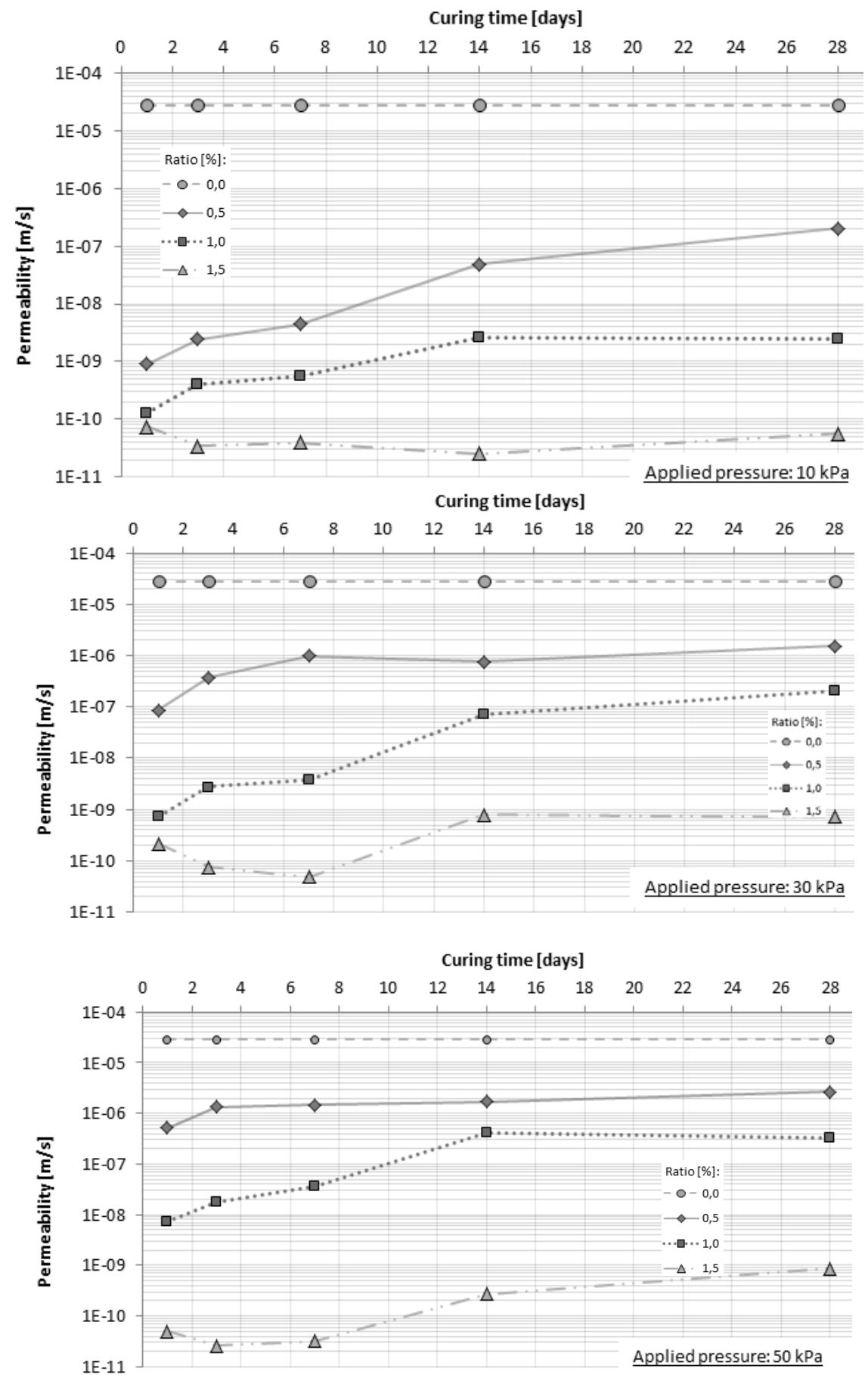

FIGURE 5. Effect of time on hydraulic conductivity of the soil biopolymer mix 

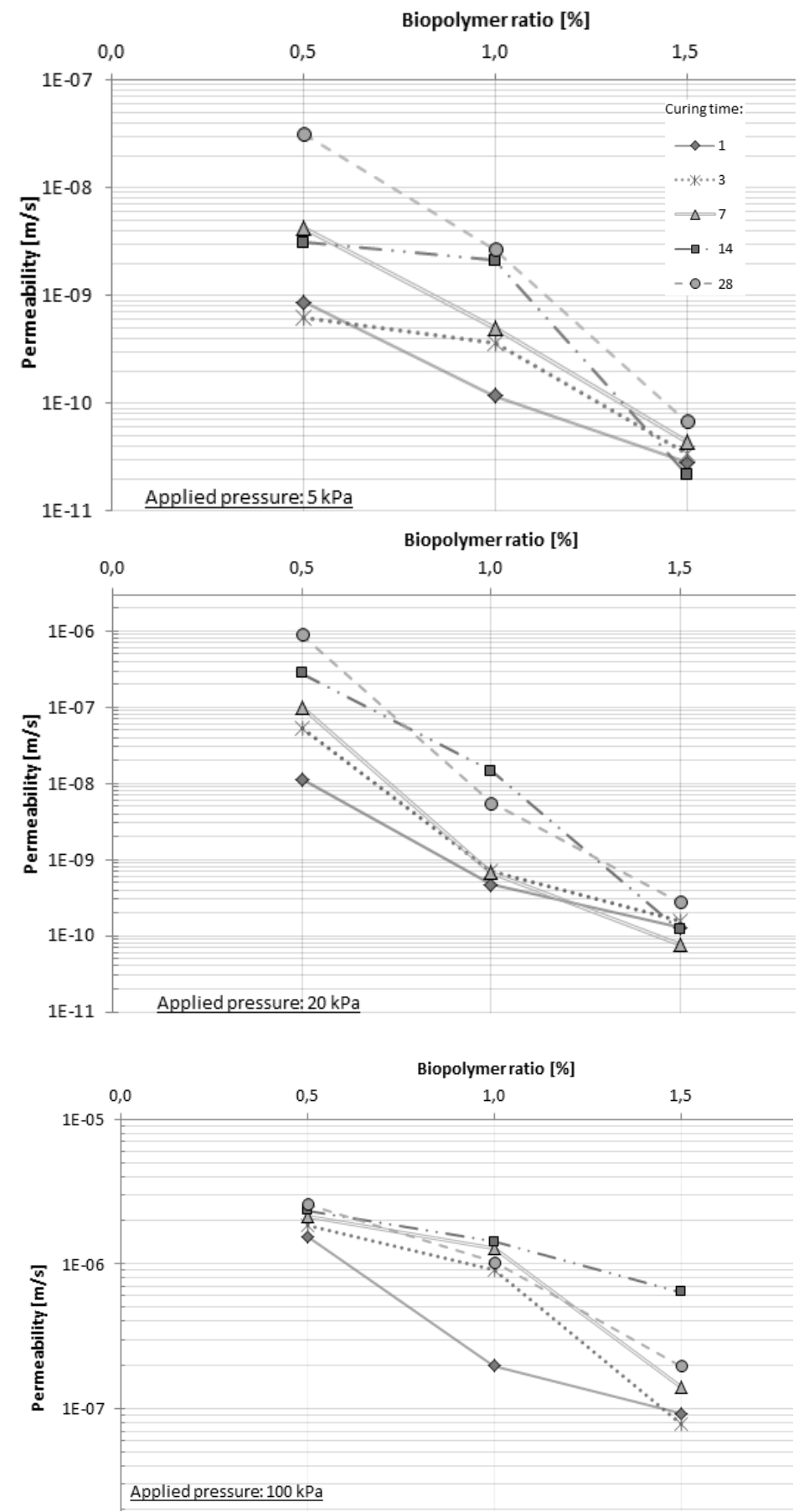

FIGURE 6. Effect of biopolymer content on hydraulic conductivity of the soil 
under pressure of $30 \mathrm{kPa}$, it increases from $3.76 \cdot 10^{-7} \mathrm{~m} / \mathrm{s}$ at 3 days to $1.53 \cdot 10^{-6} \mathrm{~m} / \mathrm{s}$ at 28 days. The ageing influence gets lower, when the xanthan gum content increases, for $1.5 \%$ mixture under pressure of $30 \mathrm{kPa}$, it increases from $7.53 \cdot 10^{-11} \mathrm{~m} / \mathrm{s}$ at 3 days to only $7.27 \cdot 10^{-10} \mathrm{~m} / \mathrm{s}$ at 28 days. Permeability remains low and stable for all 28 days, up to the hydraulic gradient value of 70 .

A polymerc chain is significant for permeation of the grout. When the biopolymer is placed in the soil matrix, it is desired to undergo some form of cross-linking in order to enhance strength and decrease its mobility in the ground. Cross-linking connects polymeric chains through chemical reactions, which might be initiated by temperature rise, change in pressure and $\mathrm{pH}$. The process can form a comprehensive lattice in the soil matrix, which rigidifies the whole polymeric structure, enhance its mechanical strength and reduce permeability (Khatami and O'Kelly, 2012).

As the effect of the biopolymer inclusion, stable permeability decrease was observed as shown in Figure 6. When the biopolymer ratio increases permeability decreases of no account of conditioning time and pressure applied. It determines a possible usage of that chemical material to create impervious barriers in the soil.

Viscous characteristics of xanthan gum have a significant meaning for stability of the soil. As observed in Figure 7 , samples mixed with the xanthan gum appeared to be much more stable. The sand grains sticked to each other, and created a linked structure. That gives another conceivable way to use of such products in the ground, for instance in slope or road embankment stability.
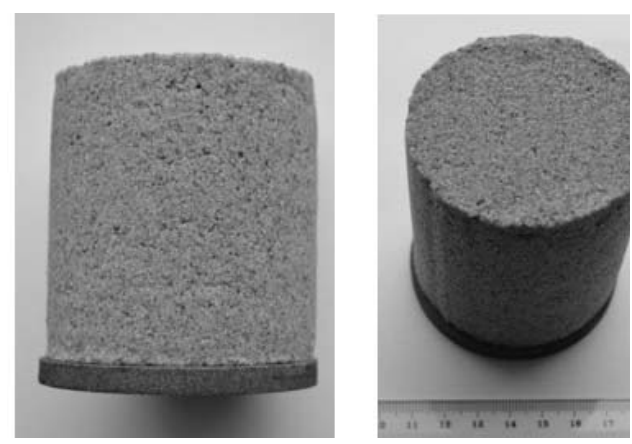

FIGURE 7. Rigid samples after testing

\section{CONCLUSIONS}

The objective of the presented study was to investigate the behavior of sandy soil and its various mixtures with xanthan gum in the terms of hydraulic conductivity. It is known that biopolymers (i.e. xanthan gum) can substantially decrease hydraulic conductivity (permeability) of soil without causing environmental toxicity.

Based on the test results which was the first part of research to investigate the influence of the biopolymer content on the reduction of the soil permeability it was proved that the permeability of medium sand treated with xanthan gum was found to be directly dependent on the biopolymer concentration.

However, on the basis of the test results the effect of curing time on changes in soil permeability cannot be fully assessed. A longer ageing time generally achieved a lower conductivity.

Also more detailed research is required to impact assessment of pore water pressure (hydraulic gradient) on hydraulic conductivity of sand-xanthan gum-water specimen.

In conclusion, biopolymer treatment occurs to be a promising technology to 
modify an engineering soils behavior. The eco-friendliness and cost of biopolymers also add to their attractiveness for use in engineering applications.

However, further studies are needed for better understanding of the use of different biopolymers and percentages with various types of soils. The future research will assess the sustainability of the changes in the structure of the soil, as a result of moisturizing-drying cyclicality, which seems to be crucial in the use of the method in hydro-engineering constructions. Mechanical testing of the shear strength in triaxial apparatus and oedometer compressibility tests have been started.

\section{REFERENCES}

ASTM D 2434-94, 2000: Standard Test Method for Permeability of Granular Soils (Constant Head). Annual Book of ASTM Standards, American Society For Testing and Materials, West Conshohocken, PA, 04.08.

BOUAZZA A., GATES W.P., RANJITH P.G. 2009: Hydraulic conductivity of biopolymer treated silty sand. Géotechnique 59(1): 71-72.

FELDMAN D. 1989: Polymeric Building Materials. Elsevier Science,

HEAD K.H., 1995: Manual of soil laboratory testing. Vol. 2. Pentech Press, London.

KARIMI S. 1997: A study of Geotechnical Applications of Biopolymer Treated Soils with an Emphasis on Silt. Phd Thesis, Civil Engineering Department, University of Southern California, Los Angeles, CA.

KHACHATOORIAN R., PETRISOR I.G., KWAN C.C., YEN T.F. 2003: Biopolymer plugging effect: laboratory-pressurized pumping flow studies. J. Pet. Sci. Engng. 38(1-2): 13-21.
KHATAMI H.R., O'KELLY B.C. 2012: Improving mechanical properties of sand using biopolymers. Journal of Geotechnical and Geoenvironmental Engineering

LI Y., YANG I.C.Y., LEE K.-I., YEN T.F. 1993: Subsurface application of Alcaligenes eutrophus for plugging of porous media. E.T. Premuzic, A.Woodhead (Eds.). Microbial Enhanced Oil Recovery - Recent Advances. Amsterdam: 65-77.

LIPIŃSKI M., KODA E., WDOWSKA M. 2007: Laboratory assessment of permeability of a groundwater protective barrier. Annals of Warsaw University of Life Sciences, Land Reclamation 30: 69-79.

MARTIN G.R., YEN T.F., KARIMI S. 1996: Application of biopolymer technology in silty soil matrices to form impervious barriers. Proceeding of 7th Australia-New Zealand Geomechanics Conference. Adelaide, Australia.

MOMENI D., KAMEL R., MARTIN G.R., YEN T.F. 1999: Potential use of biopolymer grouts for liquefaction mitigation. A. Leeson, B.C. Alleman (Eds.). Phytoremediation and Innovative Strategies for Specialized Remedial Applications 5 (6): 175-180.

STEWART T.L., FOGLER H.S. 2001: Biomass plug development and propagation in porous media. Biotechnology and Bioengineering 5: 353-363.

Streszczenie: Ocena przepuszczalności mieszaniny piasku i biopolimeru na podstawie badań laboratoryjnych. Przedstawione badania dotyczą możliwości tworzenia nieprzepuszczalnych barier $\mathrm{w}$ przepuszczalnym podłożu gruntowym z zastosowaniem dodatków biopolimeru (biosubstancji składającej się z polisacharydów i wody) mieszanych z piaszczystym gruntem podłoża. Celem przeprowadzonych badań była ocena wpływu biopolimeru na przewodność hydrauliczną piasku średniego. Badania przeprowadzono dla zawartości biopolimeru 0,5, 1,0 i 1,5\% w odniesieniu do suchej masy piasku średniego i różnych wartości gradientów hydraulicznych. Wyniki badań wskazują, że przewodność hydrauliczna znacząco zmniejsza się wraz ze wzrostem zawartości 
biopolimeru, jednakże nieznacznie wzrasta w miarę wydłużania się czasu kondycjonowania. Zastosowanie biopolimeru do tworzenia nieprzepuszczalnej bariery hydraulicznej jest stosunkowo nową techniką, którą można wykorzystać w niektórych pracach geotechnicznych, np. do zabezpieczania wykopów fundamentowych lub składowisk odpadów.

Słowa kluczowe: biopolimery, przepuszczalność, bariera przeciwfiltracyjna

MS. received December 2013
Authors' addresses:

Mateusz Wiszniewski, Ali Firat Cabalar

University of Gaziantep

Department of Civil Engineering

27310 Gaziantep, Turkey

e-mail: calabar@gantep.edu.tr

Zdzisław Skutnik

Wydział Budownictwa i Inżynierii Środowiska

Katedra Inżynierii Budowlanej

ul. Nowoursynowska 159

02-776 Warszawa

Poland

e-mail: zdzislaw_skutnik@sggw.pl 